\title{
Nānā I Ke Kumu: Look to the Source
}

I would like to begin by telling a very summarised version of the mo'olelo called 'Ka Moolelo o ko Wakea ma Noho ana ma Kalihi - Ka Loaa ana o ke Akua Ulu o Kameha'ikana'.

Wākea is a kanaka maoli (human being) and his wahine is Papa, who is called Haumea in this story; they live together in Kilohana, the pali (cliff) between Kalihi-uka and Ko'olau on O'ahu. One fine day, Haumea goes shore fishing on the Ko'olau side of the island at He'eia, while Wākea goes into the forest to gather the abundant 'ai (food) that grows there. He takes a ripe bunch of mai'a (banana), and promptly gets assaulted by the guards of the ali'i Kumuhonua. They take him to Nu'uanu, tie him to an 'ulu (breadfruit) tree, and prepare an imu to kill him in.

In He'eia, Haumea sees rain and rainbows appear over the mountain. She returns, adorns herself in the greenery of the forest, and goes to rescue her kāne. On the way she meets a man named Kali'u; she asks him to help her conduct an 'awa ceremony. In order to mix the 'awa, Haumea obtains water by throwing a pali pōhaku ${ }^{1}$, which creates the stream called Pūehuehu. Then she rescues Wākea by pretending to honi him, but actually striking the tree, into which both of them disappear.

They move to the other side of the island, taking Kali'u and his 'ohana with them. There Haumea leads them to Palikū (at Kualoa, on the border of Ko'olauloa and Ko'olaupoko), where she plans a war to overthrow the ali' $i$ who caused all this, Kumuhonua. In the meantime, the kahuna Kamoawa arrives to seek out Haumea as his ali'i.

Several battles ensue, and Haumea conducts the first one by herself. She appears as hundreds of women in a line, each holding a kukui nut in her hand. When Kumuhonua's warriors arrive looking for Wākea's warriors, the women pelt them with the kukui nuts, killing them.

Associate Professor Noenoe Silva was born on O'ahu, Hawai'i and is of Kanaka Maoli descent. She holds a Bachelor degree in Hawaiian language, a Master in Library and Information Studies and a PhD in Political Science. She is Associate Professor of Political Science at the University of Hawai'i at Mānoa. 
There are many more parts to the mo'olelo and in the end, Haumea, Wākea and the others defeat Kumuhonua and establish peace and prosperity on O'ahu.

Today we encounter this mo'olelo on microfilm. It was written by Joseph Mokuohai Poepoe in 1906 and published in the political newspaper that he owned and edited, $\mathrm{Ka} \mathrm{Na}$ ' $\mathrm{A}$ Aupuni. ${ }^{2}$ My current project is to ask how we can read such mo'olelo in order to increase our understanding of our po'e kahiko's political thought. ${ }^{3}$ What can it tell us about politics in the old world? I am using the word 'politics' broadly here to mean how people organise themselves, and also how people mitigate harms caused by those among us with drives to power; that is, to include both the struggle for power, and the ways that we collectively regulate power with systems of leadership and authority. In addition, it is important to add that in our 'ōlelo kumu (hereditary language), the word used for politics is kâlai'âina, which is something like carving land - meaning the system of who controls the land - and so, for us, politics has always concerned who controls land.

Many indigenous peoples have been re-claiming and revitalising our ancestors' languages and cultural practices. Now it is time to also research, re-think, and re-value their political thought and practices. This has been difficult because it is one of the areas, along with language and religion, which has been the most disparaged through colonialism. The original and recurring rationalisation for taking our lands and forcing conversion of our ways was that our political systems were backwards and oppressive (see Silva 2004).

Our further decolonisation should include reclaiming our traditional ways of thinking about social organisation and leadership. We have experienced hundreds of years of the extremely oppressive European systems of governance. It is time to nānā i ke kumu, or look to the source. As Ngugi says, we must decolonise our minds and this research is intended to contribute to that greater project (Ngugi 1986).

Furthermore, we must read and analyse the works of our ancestors because while foreign theories of power and politics, such as Michel Foucault's (e.g. Foucault 1980), are crucial for understanding the actions of European colonisers, they are insufficient for understanding the Kanaka 'Ōiwi, who thought deeply for thousands of years about how to organise themselves. We must newly theorise from these amazing wells of wisdom. 
And while we have to do politics in the present, that is, we have to be engaged in struggling within the current political systems, we also have kuleana (responsibility and authority) to look to our ancestors and study their ways of thinking and doing in order to change those systems so that they work for instead of against us.

With that in mind, I will now do a (necessarily) incomplete reading of this mo'olelo, and then I am going to talk about how it is the start of a larger project, and describe my research agenda.

A central principle and recurring theme in the mo'olelo, as in many mo'olelo is pono, which covers a range of concepts in English, including justice, fairness, goodness, balance, and material and spiritual well-being (Pukui and Elbert 1986: 340). Lilikalā Kame'eleihiwa, my kua'ana in this kind of work, has explained pono in this way:

\footnotetext{
... it is the reciprocal duty of the elder siblings to hanai (feed) the younger ones, as well as to love and ho'omalu (protect) them. ... it is the 'Āina (land), the kalo (taro), and the Ali' $i$ Nui who are to feed, clothe, and shelter their younger brothers and sisters, the Hawaiian people. ... Clearly, by this equation, it is the duty of Hawaiians to Mālama 'Āina (care for the land), and as a result of this proper behavior, the 'Āina will mälama Hawaiians. In Hawaiian, this perfect harmony is known as pono, which is often translated in English as 'righteous,' but actually denotes a universe in perfect harmony (Kame'eleihiwa 1992: 25)
}

The mo'olelo and mo'okū'auhau nearly always describe the reciprocal relationships between the ali'i, the kahuna, and maka'āinana, if properly in balance, as pono. This is often the central struggle in mo'olelo. Proper spiritual relationships are an integral part of this as well. Some mo'olelo are devoted to describing the struggle between male and female forces in order to create pono.

Poepoe's 'Moolelo' starts with a review of many cosmogonical stories, including a treatment of the Kumulipo, and goes on to relate mo'olelo of Papa and Wākea and other ali'i and akua. The Kumulipo and other cosmogonical mo'olelo and mele (poetry/song) are genealogies, and this mo'olelo is situated as part of these genealogies. Ali'i status - and there are many levels - is determined first by genealogy.

Poepoe's 'Moolelo Hawaii Kahiko' describes pono in political and social relationships as containing the following elements: 
the first and possibly most important for this project is that the ali' $i$ system is conceived of as pono when the ali' $i$, kahuna, and maka'āinana perform within each segment's kuleana. (I do not choose to use the word 'class' to describe these segments of society, since 'class' has a specific history in English not shared in Hawaiian culture.) If, however, ali'i take advantage of their position of power and become oppressive to others, they must be removed. Oppressive ali'i are usually killed either in war or by some fatal trick that the kahuna and/or maka'āinana perpetrate on them (see, for example, Pukui 1995). Ali'i must also listen and take the advice of the kahuna; when an ali'i fails to do so, it is a sign that the ali' $i$ is not pono. In such stories, one then expects that the ali'i will be deposed or killed. An historical example of this is the story of Kahahana, ali'i nui of O'ahu, who was conquered and killed after failing to listen to his kahuna (Kamakau 1996: 79-90; Kamakau 1992: 129-36). In Poepoe's 'Moolelo Kahiko Hawaii', Kumuhonua (also known as Kāne Kumuhonua) is known to be an oppressive ali'i who is not pono by these two characteristics. We see this in the beginning of the story, when Wākea cuts down the bunch of ripe bananas, and Kumuhonua's guards accuse him of being a thief. Kumuhonua orders that he should die by being burned alive in an imu. His supernatural mate, the archetypical woman and goddess of childbirth, war, and government, Haumea, explains in the story how wrong this action of Kumuhonua's is:

He maia ulu wale ko ke kuahiwi, he maia ma ka nahelehele, he inai na ke kini, ame ka puku'i o ka manu. No ke aha hoi i kapu ole ia ai ka manu i ka maia a kapu iho la hoi i ke kanaka? Hoouna ka hoi ua 'lii nei o oukou i kona poe kanaka, e kiu i ke kanaka e kii ana i ka mea a kona lima i luhi ole ai; a hoouna ole ka hoi oia i na kau kia manu ana e pu-lehua a e ahele i ka manu ai maia? He aha la kana. Ola ka manu ai maia, ola no hoi ke kanaka ai maia. Noonoo ole no hoi ua lii nei o oukou, he maia ke kanaka, a kona la no hoi e hua iho ai, hua no (Poepoe 1906: 9 May).

The mountains have bananas that grow wild, there are bananas in the forest, which is food for the people and for the flocks of birds. Why should the banana not be kapu to the birds, but kapu to people? That ali'i of yours has sent his people to watch for people taking something that his hands have not worked to grow; but he doesn't send any bird catchers to snare the banana-eating birds? Why? The bird who eats bananas lives, and the person who eats bananas lives. This ali'i 
of yours has failed to consider, a person is also a banana tree, whose day will come to fruit, and it will fruit.

Haumea's speech tells us that Kumuhonua is an oppressive ali'i, and why. The relationships are pono when people can gather food freely in the forest, just as the birds do. The land is there to feed the people as well as the birds. If Kumuhonua or his people had cultivated the banana, then they would have a right to the fruits of their labour. But to claim the wild bananas is an overstepping of his kuleana, and to go so far as to kill someone for taking them makes him unacceptable as a ruler. He must be removed in order for people's lives to be pono. Haumea and Wākea embark on a war against Kumuhonua to remove him.

At the colloquium, Professor Kame'eleihiwa pointed out that Wākea could be seen as at fault in this mo'olelo, since Kumuhonua was the ali' $i$ 'ai moku and had apparently set a kapu on the bananas, which Wākea violated. That gave Kumuhonua the right to punish him. I agree; however, it also seems clear to me that Haumea contests that right on the grounds that the kapu itself was not pono - it was an overstepping of kuleana.

As mentioned earlier, a good ali'i must also listen to the kahuna. When Haumea and Wākea are preparing for the war to remove Kumuhonua, the kahuna Kamoawa seeks out Kumuhonua in a quest known as imi haku (seeking a chief). Kamoawa is a skilled kahuna who is capable of seeing how the war will proceed, but Kumuhonua does not like what he hears, and tells Kamoawa to seek his chief elsewhere, specifically with Haumea and Wākea. Kamoawa then seeks out Haumea, approaching her with a prayer in her honour (Poepoe 1906: 29 May).

The other important element in establishing pono, as I said before, is the presence of all three segments of society in properly balanced, though hierarchical, relationship. The first act that Kamoawa takes as kahuna is to send for Wākea's two younger brothers. Poepoe says that Wākea, the first born, is the ali'i; Lihau'ula, the middle, is the kahuna; and Makulu, the youngest, is the maka'ainana (Poepoe 1906: 10 Mar; 1 May). The presence of all three gathered together in the story is symbolic of the three segments of society in proper relationship.

The Haumea and Wākea mo'olelo, then, is part of an orature and literature in which hierarchies are set up and legitimised, 
including the seeming hierarchy of men over women. But just as pono means that ali'i may not be oppressive or obdurate, it also means that there must be balance in the relationships between men and women. In Poepoe's story about the war with Kumuhonua, Haumea is the central figure. The major narrative line of the story celebrates Haumea's power as a female force, who is a deity that assists in childbirth, but who is also responsible for conducting warfare to restore pono. The breadfruit goddess of the title, Kāmeha'ikana, is a kino lau or body form (physical manifestation) of the goddess Haumea. Wākea is said to be a 'kanaka maoli,' a human being, while Haumea is a goddess, as well as the archetypal woman. In a pattern that is repeated in other stories, most prominently in the Hi'iakaikapoliopele cycle (Kapihenui 1862; Hooulumahiehie 1905-1906; Poepoe 1908-1911), Haumea rescues a man who is in trouble and in danger of losing his life. She has mana and strength. When Wākea is tied to the breadfruit tree, and the imu is lit in preparation to kill him, Haumea rescues him. Subsequently, Haumea battles Kumuhonua several times. She has many strengths, among them intelligence with which to strategise battles; 'ike pāpālua, with which she can see and know that which she has not yet physically seen or been told; aloha for the people which causes her to refrain from battle at times, out of sympathy for the injuries the people might suffer; and a genealogical and spiritual relationship to her ancestors, who are also land forms, specifically pali (cliffs).

This genealogical relationship to the land is another important theme in the mo'olelo. Linda Tuhiwai Smith has noted that 'Many indigenous creation stories link people through genealogy to the land, to stars and other places in the universe, to birds and fish, animals insects and plants. To be connected is to be whole' (Smith 1999: 148). Haumea can lift and throw the stone that many men could not lift, after she calls the stone a 'pali pōhaku' and offers her 'pule kuauhau kupuna' (ancestral genealogical prayer), calling on her ancestors named Palila'a, Palimoe, etc., and referring to the place named Palikū. Palikū is an actual place on O'ahu at Kualoa; it is also the 'initial point of (her) genealogy line' and an 'ancient order of priests' (Pukui and Elbert 1986: 312). Haumea arranges her battles with Kumuhonua to take place at Palikū, which connects her once again to her ancestors and the land. Kamoawa, the kahuna (which Pukui and Elbert above glossed as 'priest'), shares the Palikū genealogy with 
Haumea, in another powerful connection between the 'aina, the akua Haumea, and a human character.

We must notice here, too, that the characters in the mo'olelo are represented as simultaneously being deities, people, land, plants, and so forth. Haumea is the deity, the goddess of childbirth with supernatural powers, but she is also the man Wākea's mate and life partner; and she acquires the breadfruit tree as a kino lau and thus becomes the 'akua ulu o Kameha'ikana' (the breadfruit goddess named Kāmeha'ikana). Her ancestors are spiritual beings as well as rocks and cliffs. This is a metaphorical way to express the deep connections felt between people, the land, the plants and other life forms, and the spiritual world.

In the nineteenth century, and again late in the twentieth century, this relationship between the people and the land (and also encompassing the spiritual world) was and is expressed as 'aloha 'âina' (love for the land). The land is deity and the land is beloved family; people feed the land and the land feeds the people; the landscape itself, even rocks (or especially rocks) are part of the living world and are beloved.

The close relationships and importance of akua and ancestors is also prominent in the mo'olelo. Haumea prays to her ancestors before lifting the pali pōhaku, and again over the 'awa before giving it to Kali'u to drink. She also performs a ritual of adorning herself with the greenery of the forest before embarking on her rescue of Wākea. This forest greenery - the palapalai, lehua, maile, and $k \overline{1}$ - are the kino lau of other akua. The kahuna, Kamoawa, has Wākea construct a heiau (place of sacred ritual) before starting the battle with Kumuhonua; and at another point, when Haumea and Wākea have been taken out to sea by a tsunami, Kamoawa has Wākea create a heiau with his cupped hands, and completes a temple ritual ('aha) out at sea.

On another level, the mo'olelo is also likely to be about actual human events: the overthrow of one genealogical line - that of Kumuhonua - by another, that of Haumea, that of Palikū (the Kumulipo). Or as Poepoe puts it elsewhere in 'Ka Moolelo Hawaii Kahiko': 'Ua komo na kuauhau o ... Kumuhonua iloko o ka mookuauhau o Kumulipo' (The genealogies of Kumuhonua entered into (were absorbed into) the Kumulipo genealogy) (Poepoe 1906: 6 Feb.).

To sum up this reading, the mo'olelo tells us that our ancestors thought that society worked well when it was divided into segments, each with their proper kuleana - their 
sphere of authority and responsibility - and the necessity to care for and have aloha for each other. (Another meaning of the word kuleana is family member.)

It also tells us that things must be in balance between men and women. This was not a patriarchy; women were powerful and were leaders. Men and women lived, acted as leaders or as common people in balance with each other. And the mo'olelo also informs us that our kūpuna identified with the 'aina, saw themselves (and us) as relatives to the akua, to the mountains, the pōhaku, and the other living things in our environment. And that spirituality is an integral part of daily life and of bringing about pono.

Now, we also know that almost everything in Hawaiian literature is written metaphorically. Professor Losch has mentioned the concept called kaona. According to the PukuiElbert dictionary, kaona signifies 'hidden meaning, as in Hawaiian poetry; concealed reference, as to a person, thing, or place; words with double meanings that might bring good or bad fortune' (Pukui and Elbert 1986: 130). Pukui has elsewhere explained kaona as an inner meaning'; 'the literal meaning is like the body and the kaona is like the spirit of the poem' (Pukui 1945: 1). Kame'eleihiwa has noted that 'In the highly developed art of Hawaiian storytelling, there are always several levels of kaona in any good example of Hawaiian prose' and further, that 'Hawaiian poetry and narrative were critically judged by their audience as sophisticated or simple, depending on the levels of kaona' (Kame'eleihiwa 1996: ix).

The readers of the mo'olelo when it was published in 1906 undoubtedly understood it to contain many levels of meaning. When Wâkea is taken and condemned to die for the ordinary act of gathering food, for example, it is possible that readers made a mental connection between that injustice and similar injustices in their own lives, in which everyday practices such as speaking their own language or drinking 'awa had been banned or even criminalised (see Merry 1998). Another example is that they would have understood kaona in Haumea's choice of weapon being kukui nuts thrown at the foreheads of Kumuhonua's warriors. Kukui nuts were used in traditional times as lamps, their oil providing a slow-burning fuel for light. Light (mālamalama or ao) is a common metaphor for knowledge, education, and wisdom in Hawaiian, just as it is in English. A kukui nut thrown at the forehead, then, might easily be understood as a metaphor for the superiority of intelligence or wisdom as a weapon. 
Now it is also worthwhile to contextualise the publication of this mo'olelo - who wrote it, in what venue, and for what reasons.

The mo'olelo, as I said, has a mea kākau - a writer - it does not just appear as a messenger from the past. It is a created work of literature based on the oral traditions. We do need to credit the labour and the art that has gone into the work. The author is Joseph Mokuohai Poepoe, an attorney and legislator, but more important, a prolific and eloquent writer of several different genres of mo'olelo, including histories; biographies; 'mo'olelo ka'ao', the stories of the akua and 'aumakua and kupua of the past; and mo'oku' 'auhau.

In the introduction to this mo'olelo, he explained his reasons for undertaking this work:

Ke hoopuka aku nei makou ... i ka Moolelo Kahiko o Hawaii nei, e like me ia i hoomakaukau ia a kakauia e ka lunahooponopono o keia nupepa, a ke lana nei ko makou manao e lilo ana keia mahele i mea e pulamaia e na Opio Hawaii (Poepoe 1906, 1 Feb.).

We are publishing the Moolelo Kahiko O Hawaii nei, as has been prepared and written by the editor of this paper, and we are hoping that this part of the Moolelo of Hawaii will become something cherished by Hawaiian Youth.

Ua hoalaia ae keia hana e ka Mea Kakau no kona makee a minamina maoli i ka moolelo e pili ana i ka hana, ka nohona ame na manao o ko Hawaii nei kupuna i hala aku i ka po.

This work was begun by the Author because of his desire and true valuing of the mo'olelo concerning the work, the life, and the ideas of Hawai'i's ancestors who have passed into the pō.

Poepoe was also doing scholarly work here. He says,

ua hoakoakoaia, hoiliiliia, hoouluuluia a hoonohonohoia na mahele o keia Moolelo, mai loko mai o na mele, na kuauhau a me na moolelo i paa ma na buke, i kakaulimaia a pa'i maoli ia a kekahi poe loea pili moolelo, a pela pu no hoi mailoko mai o kekahi mau nupepa kahiko i loaa mai i ka mea kakau.

The sections of this Moolelo have been collected, gathered together, summarised, and arranged, from within the mele (songs and chants), genealogies, and stories which have been preserved in books, and also from some old newspapers belonging to the author. 
Poepoe prized this knowledge very highly: he published not only this 'Moolelo Kahiko' but also a biography of Kamehameha I (Poepoe 1905), at least one and probably two different, long, versions of the epic of Hi'iakaikapoliopele (Hooulumahiehie 1905; Poepoe 1908), a very long and eloquent version of the mo'olelo of Kawelo (Hooulumahiehie 1909), and other mo'olelo. His versions were written and published at a time when the Americanisation of Hawai'i was accelerating, and when there were was still a large population of readers of Hawaiian, but before WW1, after which it became harder for the Kanaka Maoli to openly retain their own cultural-linguistic and national identity.

Elsewhere in this volume, Rahera Ka'ai-Mahuta has said that everything has a whakapapa, and I agree. As indigenous intellectuals we have a whakapapa, too. We have a wealth of writing in Hawaiian that was published in newspapers between 1834 and 1948, as Kumu Losch told us earlier. I therefore see us now taking up Poepoe's work; we are in a whakapapa or mo'oku'auhau of scholarship with Samuel Kamakau in the mid-19th century writing down as much of ka mo'olelo kahiko as he could, and with Poepoe in the late 19th early $20^{\text {th }}$ centuries, again consciously writing down for us as much as he could before he died. We have kuleana - the responsibility as well as the authority - to do this work, to follow on this path, although at times it seems that it is too big, too much. But if not us, who? And the situation has not changed much - if we don't try to understand our kūpuna's ways of thinking and doing, we will stay stuck in our colonial situation. And others will keep interpreting for us.

Both Kamakau and Poepoe believed in reading, telling, rewriting, and interpreting the mo'olelo kahiko. And now we can add the word theorising. I like this quote from Barbara Christian:

People of color have always theorised--but in forms quite different from the Western form of abstract logic. And I am inclined to say that our theorizing (and I intentionally use the verb rather than the noun) is often in narrative forms, in the stories we create, in riddles and proverbs, in the play with language, since dynamic rather than fixed ideas seem more to our liking. How else have we managed to survive with such spiritness the assault on our bodies, social institutions, countries, our very humanity? (quoted in Sinavaiana-Gabbard $2001,175)$ 
Now besides the several well-known authors, there are many authors of works in the newspapers. In one 'ethnological' index done by Kawena Pukui, there are over 200 names (Hawaiian Ethnological Notes). And this index only includes what was of interest to the project of ethnology at the Bishop Museum.

Considering that these hundreds of lesser-known Kanaka writers studied European and American law and politics along with their own traditions, reasoned from within Hawaiian epistemologies, and publicly contended with each other and with foreigners, study of what they wrote is not only warranted, but will allow us to dramatically increase our understanding of both traditional and anti-colonial indigenous political thought and action.

So now my research agenda, which I am sharing with my graduate students in Hawaiian language and political science, is to systematically map the political thought as it appeared in the Hawaiian language newspapers - to track writers and their productions. I want to learn what Kanaka traditional thought informed their politics in their own eras.

The graduate students in the Hawaiian language MA program research methods class did two projects in Spring 2006. For the first, each was assigned a fairly early newspaper, for which they compiled databases of the titles and writers of every significant letter, story, and mele in their newspaper. At the end of the project, after merging all their databases into one, we now have a database of over 2,000 entries, with at least twenty-five authors of six or more works whose names were not recorded in Pukui's Hawaiian Ethnological Notes. ${ }^{4}$

The second project is that each chose an author that interested them and compiled as complete a bibliography of that author's work as possible in the time we had. Each student also researched the life of the author, and then after reading his or her works, produced a paper that described the author and the kinds of writing he or she did. Several of the papers were excellent and added substantially to our collective knowledge of the works of S.N. Haleole (Kalei Tsuha), Kahikina Kelekona aka John Sheldon (Iokepa Badis), and S.K. Kuapu'u (Kaluhialoha Eldridge) especially.

After doing this for several years, we should be able to start mapping who the thinkers and writers in the $19^{\text {th }}$ and $20^{\text {th }}$ centuries were, and what kinds of ideas they felt moved to bring into the public sphere. Then we can analyse even better 
how much and in what ways traditional Hawaiian thinking informed politics and governance in those eras.

\section{Conclusion}

For final thoughts, I want to reiterate where I began: I think it is important for our mental decolonisation to go to these stories and recuperate our ancestors' knowledge about how they organised themselves politically. This is bound to reveal much that will be of benefit to us today.

Additionally I think it is useful to ask these kinds of questions for each of the writers (taking Poepoe as an example): what was Poepoe himself doing politically by publishing this and the other mo'olelo? His and other Hawaiian language publications supported indigenous Hawaiian thought and resisted cultural and linguistic genocide; Poepoe's eloquent language was meant to inspire young people to become as highly skilled in the language, and to learn the ancient mele and mo'oku'auhau. In other words, to kūpa'a, 'onipa'a i nā 'ano Hawai'i (remain steadfast in our ancestors' Hawaiian ways). To refuse to become Americans, really. In this way, Poepoe was fighting for our language and culture. We have to fight for them, too, as scholars and as writers.

\section{Bibliography}

Foucault, M. 1980. Power/knowledge: selected interviews and other writings, 1972-1977. Transl. Colin Gordon. New York: Pantheon Books.

Kamakau, S. M. 1991. Na Mo'olelo a ka Po'e Kahiko (Tales and Traditions of the People of Old). Honolulu: Bishop Museum Press.

Kamakau, S. M. 1996. Ke Kumu Aupuni (Te Source of Government). Honolulu: 'Ahahui 'Olelo Hawai'i.

Kame'eleihiwa, L. 1996. He Mo'olelo Ka'ao o Kamapua'a: A Legendary Tradition of Kamapua'a the Hawaiian Pig-God. Honolulu: Bishop Museum Press.

Kapihenui, M. J. 1861-62. 'He mooolelo no Hiiakaikapoliopele', in Ka Hoku O Ka Pakipika (serialised between 26 Dec. 1861 and 17 July 1862).

Merry, S.E. 1998. 'The Criminalization of everyday life', in A. Sarat. (ed) Everyday practices and trouble cases. Evanston, IL: Northwestern University Press. pp. 14-40.

Ngugi Wa Thiong'o. 1986. Decolonising the mind: The politics of language in African literature. Portsmouth, New Hampshire: Heinemann.

Poepoe, J.M. 1906. 'Ka moolelo Hawaii kahiko', in Ka Na'i Aupuni (serialised between 1 February and 4 August 1906).

Poepoe, J.M. 1908. 'Ka Mo'olelo o Pele me Hi'iakaikapoliopele.' Honolulu: Ku'oko‘a Home Rula. 
Poepoe, J.M. 1908-1911. 'Ka moolelo kaao o Hiiakaikapoliopele', in Kuokoa Home Rula (serialised from January 1908 to January 1911).

Pukui, M.K. \& S. Elbert. 1986. Hawaiian Dictionary. Rev. ed. Honolulu: University of Hawai'i Press.

Pukui, M.K. 1945. 'Hawaiian poetry and music', unpublished lecture at Kamehameha Schools. University of Hawai'i at Mānoa Hamilton Library.

Silva, N. K. 2004. Aloha betrayed: Native Hawaiian resistance to American colonialism. Durham, NC: Duke University Press.

Sinavaiana-Gabbard, C. 2001. 'Modelling community: A response to the oceanic imaginary.' The Contemporary Pacific. 13 (2): 169-175.

Smith, L.T. 1999. Decolonising Methodologies: Research and Indigenous Peoples. Dunedin: University of Otago Press.

\section{Notes}

1 There is no adequate translation for this phrase-by the logic of the phrase, it should be something like 'stone (pōhaku) cliff (pali)'. My interpretation is that it is a very tall stone, with the word pali used figuratively. The reason for this particular word choice will become apparent later in the mo'olelo.

2 Although the 'okina here may seem anachronistic, in fact Poepoe used an apostrophe to indicate the glottal stop in his spelling of the paper's title.

Po'e kahiko are the people of old.

Those students are Iokepa Badis, Mele-'Āina Dancil, Kaluhialoha Eldridge, Kāhealani Lono, Ululani Oliva, Kellen Paik, Kenneth Segawa, Kalei Tsuha, and Ron Williams, Jr. 